Bangl. J. Vet. Med. (2009). 7(1) : $269-274$

\title{
SERO-PREVALENCE STUDY OF BRUCELLOSIS IN CATTLE AND CONTACT HUMAN IN MYMENSINGH DISTRICT
}

\author{
A. Nahar and M. U. Ahmed \\ Department of Medicine, Faculty of Veterinary Science, Bangladesh Agricultural University, Mymensingh-2202, \\ Bangladesh.
}

\begin{abstract}
A cross-sectional survey was conducted to determine the seroprevalence of brucellosis in cattle and in contact human in Veterinary Clinic and Dairy Farm of Bangladesh Agricultural University (BAU) from June 2007 to November 2007. A total of 200 sera samples from cattle and 50 sera samples from human were collected from BAU Veterinary Clinic and USDA funded Red Chittagong cattle project at BAU Dairy Farm. Questionnaire based data on risk factors were collected both in cattle and in contact human. Sera were separated from blood samples and tested with the Rose Bengal Test (RBT) and Standard Tube Agglutination Test (STAT) parallely. Multiple logistic regression was used to identify risk factors of brucellosis both in cattle and in contact human using SPSS ${ }^{\mathbb{R} .}$ The overall seroprevalence of brucellosis in cattle and in contact human were found $4.5 \%$ and $6 \%$ respectively. Statistically insignificant higher seroprevalence of brucellosis was found in cattle aged above 4 years and in human aged above 30 years, in Red Chittagong cattle of BAU dairy farm, in female of cattle and in male of human, in cattle with grazing, in pregnant cows, in animal owner and in human with smoking.
\end{abstract}

Key words: Seroprevalence, Rose Bengal Test (RBT), Standard Tube Agglutination Test (STAT)

\section{INTRODUCTION}

Brucellosis is the most widespread zoonoses worldwide (Mustafa \& Nicoletti, 1995; Acha \& Szyfres, 2001). The genus Brucella has six recognized species on the basis of host specificity. Among all six species of Brucella, the greatest economic impact results from bovine brucellosis caused by $B$. abortus. It has been recognized as a cause of reproductive failure in dairy cattle, thereby causing significant economic losses through calf loss, in costs for regulatory and eradication. Human brucellosis results from direct contact with infected livestock and livestock products and infection can be transmitted to consumers through raw milk and milk products. Most cases occur in people employed in meat processing industry while sources include the domestic cattle, pig, sheep, goat and unpasteurized dairy products (Radostits, 2000). The importance of brucellosis is primarily due to its public health significance and to economic loss to the animal industry (WHO, 1971). It can have socioeconomic impacts, especially in which rural income relies largely on livestock breeding and dairy products (Islam et al., 1983). Prevalence of brucellosis has been reported in cattle and in human from different parts of the world. Brucellosis is endemic in Bangladesh (Rahman et al., 1978) and was first reported in cattle in 1967 (Mia and Islam, 1967). Human brucellosis was first reported in Bangladesh by Rahman et al. (1983). Rahman et al. (1983) reported higher prevalence of brucellosis in cows of better-managed farms and estimated of human brucellosis as $12.8 \%$ in herders and agricultural workers and as $21.6 \%$ in goat farmers. Rahman et al. (2006) reported the animal-level seroprevalence of brucellosis in cattle as $2.4 \%-18.4 \%$ while the herd-level seroprevalence in cattle as $62.5 \%$ in Bangladesh. Rahman et al. (1988) estimated of human brucellosis as $15 \%$ in milking parlour and dairy workers in Bangladesh. There is scant information about the prevalence and risk factors of brucellosis in cattle and in contact human in Bangladesh context using an appropriate study design. Therefore the present study was carried out to determine the prevalence and distribution of brucellosis in cattle and in contact human and to identify risk factors of brucellosis in cattle and in contact human.

\section{MATERIALS AND METHODS}

The study was conducted for a period of 6 months from June 2007 to November 2007 in the Department of Medicine, Faculty of Veterinary Science, Bangladesh Agricultural University, Mymensingh to determine the seroprevalence of brucellosis in cattle and in contact human. A total of 200 sera samples from cattle and 50 sera samples from human were collected from BAU Veterinary Clinic and USDA funded Red Chittagong cattle project at BAU Dairy Farm. Among cattle sera samples, 151 sera samples were collected from BAU Veterinary Clinic and 49 sera samples were collected from Red Chittagong cattle of USDA project nucleus herd at BAU Dairy Farm. Among human sera samples, 26 sera samples from students of Faculty of Veterinary Science, 7 sera samples from animal owners, 13 sera samples from clinical attendants of BAU Veterinary Clinic and BAU dairy 


\section{A. Nahar and M. U. Ahmed}

farm, and 4 sera samples from butchers were collected. In case of cattle, questionnaire based data on age, gender, breed, area, pregnancy status, grazing pattern were recorded . Similarly for in contact human, questionnaire based data on age, gender, type of contact and habit of smoking were recorded.

\section{Blood and Sera Samples Collection}

At first the animal was controlled by the owner and attendant and then the site of blood collection at jugular furrow was soaked with tincture of iodine. About 7-10 $\mathrm{ml}$ of blood was collected from jugular vein of each of cattle and 5-7 ml blood from radial vein of each of human with the help of sterile disposable syringe and needle and was kept undisturbed on a tray for at least $30 \mathrm{~min}$. at room temperature in a slightly inclined position to facilitate clotting and separation of serum. After this period, the clotted blood samples with sera are transferred to refrigerator at $4^{0} \mathrm{C}$ and kept overnight. Later on, the sera were poured into the separate test tube from each labeled syringe and the test tube was marked with same number by permanent marker. Then the sera were centrifuged at $2500 \mathrm{rpm}$ for $10 \mathrm{~min}$. After centrifugation a clear sera were found and then the sera were transferred to the vial. The vial was stored in ice chamber at $-20^{\circ} \mathrm{C}$ for use.

\section{Serological Study}

Rose Bengal Test (RBT) and Standard Tube Agglutination Test (STAT) were used for diagnosis of brucellosis. Sera were separated from blood samples and tested with the Rose Bengal Test and Standard Tube agglutination test parallely.

\section{Rose Bengal Test}

The test was performed according to the procedure as described by OIE, 2004. The control sera, test serum samples and Rose Bengal antigen (INSTITUT POURQUIER-326 Rue de la Galera-34090 MONTPELLIERFRANCE, prepared by concentrated suspension of Brucella abortus Weybridge stain 99) were kept for 1 hour in room temperature before beginning of the test. The test sera samples and control sera were homogenized using a vortex (Shaker). Thirty (30) $\mu 1$ of each serum to be tested was placed on a glass plate circled approximately $2 \mathrm{~cm}$ in diameter. Then the vial of antigen was shaked gently and $30 \mu l$ of antigen was put beside each of the sera. The antigen and serum were mixed on the plate for exactly 4 minutes, the reading was taken immediately. The result was considered positive when there was any degree of agglutination noticeable.

\section{Standard Tube Agglutination Test}

This test is mostly wide used of all serological test for brucellosis and simple to perform (Memish et al., 2002).Smooth whole cells of Brucella abortus were used as antigen for detection of Brucella specific IgG and IgM antibodies. At first serum samples were diluted in saline $(\mathrm{NaCl} 9 \mathrm{~g} / \mathrm{L})$. A row of test tubes was prepared for antigen started from 1:20 upto1:320. Two tubes were prepared for positive and negative control using $0.1 \mathrm{ml}$ control $+0.9 \mathrm{ml} \mathrm{NaClg} / \mathrm{L}$. A drop of antigen suspension after shaking was added to each tube and mixed thoroughly. Then the test tubes were incubated at $37^{\circ} \mathrm{c}$ for 24 hours. After indicated period of time, reading was taken to observe the presence or absence of agglutination. In positive cases, of brucellar antigen,a clear granular agglutination was appeared .In negative reaction(including negative control) the suspension was remained unchanged. The titre of highest dilution giving positive result.

\section{Data processing and statistical analysis}

The questionnaire based data were entered in Microsoft Excel 2003 and transferred to SPSS ${ }^{\circledR}$ for statistical analysis. Multiple logistic regressions were used to identify risk factors of brucellosis both in cattle and in contact human using software SPSS ${ }^{\mathbb{R}}$.

\section{RESULTS AND DISCUSSION}

In the present study, the overall seroprevalence of brucellosis was $4.5 \%$ in cattle (Table 1 ) which is higher than the overall seroprevalence of brucellosis, 2\% reported by Amin et al. (2004) and 2.33\% reported by Amin (2003). But this finding is in agreement with Rahman et al. (2006) who reported animal-level seroprevalence of brucellosis in cattle is $2.4 \%-18.4 \%$ while the herd-level seroprevalence in cattle is $62.5 \%$.

The overall seroprevalence of brucellosis was $6 \%$ in contact human (Table 1) which is lower than seroprevalence of brucellosis, $12.8 \%$ reported by Rahman et al. (1983). This is due to majority (26 out of 50) of human samples was taken from the students of the Faculty of Veterinary Science who are less exposed to animal contact than animal attendants. 
A statistically insignificant higher prevalence of brucellosis was found in cattle aged above 4 years $(4.34 \%)$ than that aged below 4 years $(3.82 \%)$ shown in Table 2 . The findings correlate with the observation of Sarumathi et al. (2003); Amin (2003) and Amin et al.(2004). So, it may be considered that the higher prevalence of brucellosis among older cattle might be due to maturity with the advance age. However, the older animals are supposed to be more infected, because of more contact with infectious agents and sometimes from malnutrition during pregnancy.

Table1. Overall seroprevalence of Brucellosis in cattle and in contact human

\begin{tabular}{lcc}
\hline Species & Total number of sera samples collected \& tested & Total number and \% of positive cases \\
\hline Cattle & 200 & $9(4.5)$ \\
Human & 50 & $3(6)$ \\
\hline
\end{tabular}

A statistically insignificant higher prevalence of brucellosis was recorded in human aged above 30 years $(11.12 \%)$ whereas the minimum prevalence rate of brucellosis in human aged below 20 years $(0.0 \%)$ by both RBT and STAT (Table 2). So, it may be considered that the worst affected group was young adults to adults. Similar reports were recorded by Mrunalini et al. (2004).

Table 2. Age wise distribution of brucellosis in cattle and in contact human

\begin{tabular}{clccccc}
\hline Species & $\begin{array}{c}\text { Age of cattle and } \\
\text { human }\end{array}$ & Sera Tested & $\begin{array}{c}\text { Number \& \% of } \\
\text { sera positive by } \\
\text { RBT }\end{array}$ & $\begin{array}{c}\text { Total number } \\
\& \% \text { of sera } \\
\text { positive by } \\
\text { RBT }\end{array}$ & $\begin{array}{c}\text { Number \& \% } \\
\text { of sera } \\
\text { positive by } \\
\text { STAT }\end{array}$ & $\begin{array}{c}\text { Total No. \& } \% \\
\text { of sera positive } \\
\text { by STAT }\end{array}$ \\
\hline \multirow{2}{*}{ Cattle } & 0-4 yrs & 131 & $5(3.82)$ & $200(4)$ & $5(3.82)$ & $200(4.5)$ \\
& Above 4 yrs & 69 & $3(4.3)$ & & $4(5.8)$ & $0(0)$ \\
\multirow{5}{*}{ Human } & Below 20 yrs & 3 & $0(0)$ & & $2(5.27)$ & $50(6)$ \\
& 20-30 years & 38 & $2(5.27)$ & $50(6)$ & $1(11.12)$ & \\
\hline
\end{tabular}

A statistically insignificant higher prevalence of brucellosis in cattle was observed in female (5.04\%) by STAT than male $(2.44 \%$ ) by both RBT and STAT (Table 3 ). This finding was similar to the findings recorded by Sharma et al. (2003). A statistically insignificant higher prevalence of brucellosis in human was found in male $(6.82 \%)$ than female $(0 \%)$ by both RBT and STAT (Table 3$)$. This finding was correlated with observation of Sharma et al. (2003).

Table 3. Gender wise distribution of brucellosis in cattle and in contact human

\begin{tabular}{ccccccc}
\hline Species & $\begin{array}{c}\text { Age of } \\
\text { cattle and } \\
\text { human }\end{array}$ & Sera Tested & $\begin{array}{c}\text { Number \& \% of } \\
\text { sera positive by } \\
\text { RBT }\end{array}$ & $\begin{array}{l}\text { Total number \& of sera } \\
\text { positive by RBT }\end{array}$ & $\begin{array}{c}\text { Number \& \% of } \\
\text { sera positive by } \\
\text { STAT }\end{array}$ & $\begin{array}{c}\text { Total No. \& \% } \\
\text { of sera positive } \\
\text { by STAT }\end{array}$ \\
\hline \multirow{2}{*}{ Cattle } & Male & 41 & $1(2.44)$ & & $1(2.44)$ & \\
& Female & 159 & $7(4.41)$ & $200(4)$ & $8(5.04)$ & $200(4.5)$ \\
Human & Male & 44 & $3(6.82)$ & & $0(6.82)$ & $0(0)$ \\
\hline
\end{tabular}

A statistically insignificant higher prevalence was found in Red Chittagong cattle of USDA project Nucleus Herd at BAU dairy farm $(4.09 \%)$ at organized farm than that of BAU veterinary Clinic coming for treatment (3.98\%) from rural areas (Table 4). Similar results were also reported to be prevalent by other investigators (Agunloye et al., 1988; Boro et al., 1981; Sharma et al., 2003).

The prevalence of brucellosis was lower in indigenous breed $(2.5 \%$ by STAT) than cross breed $(5.84 \%)$ shown in Table 5. This may be due to genetic factors that made indigenous breed resistant to the infection.

A statistically insignificant higher prevalence of brucellosis was found in pregnant cows (12.25\% by STAT) than non-pregnant cows (2\%) shown in Table 6. Similar results were reported by Amin et al. (2004) and they recorded $3.45 \%$ in pregnant cows than in non-pregnant cows $(1.23 \%)$. This finding correlates with the observation of Amin (2003) and Plommet (1971). 


\section{A. Nahar and M. U. Ahmed}

Table 4. Area wise distribution of brucellosis in cattle

\begin{tabular}{ccccccc}
\hline Species & Area of investigation & $\begin{array}{c}\text { Sera } \\
\text { Tested }\end{array}$ & $\begin{array}{c}\text { Number \& \% of } \\
\text { sera positive by } \\
\text { RBT }\end{array}$ & $\begin{array}{c}\text { Total number } \\
\text { \& of sera } \\
\text { positive by } \\
\text { RBT }\end{array}$ & $\begin{array}{c}\text { Number \& \% } \\
\text { of sera } \\
\text { positive by } \\
\text { STAT }\end{array}$ & $\begin{array}{c}\text { Total No. \& \% } \\
\text { of sera positive } \\
\text { by STAT }\end{array}$ \\
\hline Cattle & $\begin{array}{c}\text { BAU Veterinary } \\
\text { Clinic }\end{array}$ & 151 & $6(3.98)$ & $200(4)$ & $7(4.64)$ & $200(4.5)$ \\
\hline
\end{tabular}

A statistically insignificant higher prevalence of brucellosis was found in cattle with grazing (4.77\%) by RBT than in cattle without grazing (3.65\% by RBT) shown in Table 7. Similar was reported by Silva et al. (2000). The author stated that this may be due to unrestricted contact between animals.

Table 5. Breed wise distribution of brucellosis in cattle

\begin{tabular}{ccccccc}
\hline Species & Type of breed & Sera Tested & $\begin{array}{c}\text { Number \& \% of } \\
\text { sera positive by } \\
\text { RBT }\end{array}$ & $\begin{array}{c}\text { Total number } \\
\& \% \text { of sera } \\
\text { positive by } \\
\text { RBT }\end{array}$ & $\begin{array}{c}\text { Number \& \% of } \\
\text { sera positive by } \\
\text { STAT }\end{array}$ & $\begin{array}{c}\text { Total No. \& } \% \\
\text { of sera positive } \\
\text { by STAT }\end{array}$ \\
\hline \multirow{2}{*}{ Cattle } & $\begin{array}{c}\text { Indigenous } \\
\text { Cross }\end{array}$ & 80 & $2(2.5)$ & $200(4)$ & $2(2.5)$ & $200(4.5)$ \\
\hline
\end{tabular}

The prevalence of brucellosis was highest in animal owner among others (Table 8). This may be due to unsafe handling of infected animal and materials and lack of awareness. This finding is similar to the observation reported by Jiksa et al. (2006). This study also revealed that there was no positive cases among butchers this may be due to small number of samples were tested.

Table 6. Distribution of brucellosis in pregnant and non pregnant cattle

\begin{tabular}{lcccccc}
\hline Species & $\begin{array}{c}\text { Criteria of } \\
\text { animals }\end{array}$ & $\begin{array}{c}\text { Number of sera } \\
\text { samples collected } \\
\text { and tested }\end{array}$ & $\begin{array}{c}\text { Number \& } \% \\
\text { of sera positive } \\
\text { by RBT }\end{array}$ & $\begin{array}{c}\text { Total No. \& \% } \\
\text { of sera } \\
\text { positive by } \\
\text { RBT }\end{array}$ & $\begin{array}{c}\text { Number \& \% } \\
\text { of sera } \\
\text { positive by } \\
\text { STAT }\end{array}$ & $\begin{array}{c}\text { Total No. \& } \\
\% \text { of sera } \\
\text { positive by } \\
\text { STAT }\end{array}$ \\
\hline \multirow{2}{*}{ Cattle } & $\begin{array}{c}\text { Non pregnant } \\
\text { Pregnant }\end{array}$ & 100 & $2(2)$ & 149 & $2(2)$ & $149(5.37)$ \\
\hline
\end{tabular}

A statistically insignificant higher prevalence of brucellosis was found in human with smoking (7.41\%) than human without smoking (Table 9). This may be due to transmission of infection through inhalation.

Table 7. Distribution of brucellosis with grazing in cattle

\begin{tabular}{lcccccc} 
Species & $\begin{array}{c}\text { Types of } \\
\text { Grazing }\end{array}$ & $\begin{array}{c}\text { Number of } \\
\text { sera samples } \\
\text { collected and } \\
\text { tested }\end{array}$ & $\begin{array}{c}\text { Number \& \% of } \\
\text { sera positive by } \\
\text { RBT }\end{array}$ & $\begin{array}{c}\text { Total No. \& } \\
\% \text { of sera } \\
\text { positive by } \\
\text { RBT }\end{array}$ & $\begin{array}{c}\text { Number \& \% } \\
\text { of sera } \\
\text { positive by } \\
\text { STAT }\end{array}$ & $\begin{array}{c}\text { Total No. \& } \\
\% \text { of sera } \\
\text { positive by } \\
\text { STAT }\end{array}$ \\
\hline \multirow{2}{*}{ Cattle } & Yes & 63 & $3(4.77)$ & 200 & $3(4.77)$ & $200(4.5)$ \\
\hline
\end{tabular}


Table 8. Distribution of brucellosis based on type of contact in contact human

\begin{tabular}{llccccc}
\hline Species & \multicolumn{1}{c}{ Type of contact } & Sera Tested & $\begin{array}{c}\text { Number \& } \% \\
\text { of sera } \\
\text { positive by } \\
\text { RBT }\end{array}$ & $\begin{array}{c}\text { Total number } \\
\& \% \text { of sera } \\
\text { positive by } \\
\text { RBT }\end{array}$ & $\begin{array}{c}\text { Number \& } \% \\
\text { of sera } \\
\text { positive by } \\
\text { STAT }\end{array}$ & $\begin{array}{c}\text { Total No. \& } \\
\% \text { of sera } \\
\text { positive by } \\
\text { STAT }\end{array}$ \\
\hline \multirow{3}{*}{ Human } & Clinical attendant & 13 & $1(7.7)$ & & $1(7.7)$ & $1(14.29)$ \\
& $\begin{array}{l}\text { Animal owner } \\
\text { Butchers }\end{array}$ & 7 & $1(14.29)$ & & $0(0)$ & $50(6)$ \\
& $\begin{array}{l}\text { Students of faculty of } \\
\text { veterinary science }\end{array}$ & 26 & $1(3.85)$ & & $1(3.85)$ & \\
\hline
\end{tabular}

Table 9. Distribution of brucellosis with smoking in contact human

\begin{tabular}{lcccccc}
\hline Species & Smoking & $\begin{array}{c}\text { Sera } \\
\text { Tested }\end{array}$ & $\begin{array}{c}\text { Number \& \% of } \\
\text { sera positive by } \\
\text { RBT }\end{array}$ & $\begin{array}{c}\text { Total number \& } \\
\text { \% of sera } \\
\text { positive by RBT }\end{array}$ & $\begin{array}{c}\text { Number \& \% of } \\
\text { sera positive by } \\
\text { STAT }\end{array}$ & $\begin{array}{c}\text { Total No. \& \% of } \\
\text { sera positive by } \\
\text { STAT }\end{array}$ \\
\hline \multirow{2}{*}{ Human } & Yes & 27 & $2(7.41)$ & $50(6)$ & $2(7.41)$ & $1(4.35)$ \\
\hline
\end{tabular}

Therefore, the present study revealed that prevalence and risk factors of brucellosis are greatly influenced by age, gender, breed, area, pregnancy status, grazing pattern in cattle and age, gender, type of contact, habit of smoking in contact human. For further studies, isolation and characterization of Brucella organism as well as type of Brucella are recommended.

\section{REFERENCES}

1. Acha P and Szyfres B (2001). Brucellosis. In: Zoonoses and communicable diseases common to man and animals. 3rd edn., Vol.3, Pan American Health Organization, editors. Washington. P.40-65.

2. Agunloye CA, Esuruoso GO and Ajogi I (1988). Bovine brucellosis surveillance in N' Dama breeding herd in Nigeria. Veterinary Bulletin 50 (9): 716.

3. Amin KMR (2003). Serological epidemiology of bovine and caprine brucellosis. MS thesis. Department of Microbiology and Hygiene, Bangladesh Agricultural University, Mymensingh-2202, Bangladesh.

4. Amin KMR, Rahman MB, Kabir SML, Sarker SK and Akand MSI (2004). Serological epidemiology of brucellosis in cattle of Mymensingh districts of Bangladesh. Journal of Animal Veterinary Advances 3(11): 773-775.

5. Boro BR, Chakraborty AK, Das SK and Broa J (1981). A preliminary serological survey of brucellosis in Mithuns (Bos genus) in Arunachal Pradesh. Indian Veterinary Journal. 88: 586-587.

6. Islam A, Haque M, Rahman A, Rahman MM, Rahman A and Haque F (1983). Economic losses due to brucellosis among cattle in Bangladesh. Bangladesh Veterinary Journal 17(1-4): 57-62.

7. Jiksa K, Eshetu Y, Abera G, Paulos A, Bethlehem N, Badeg Z, Mekoro B and Abebe B (2006). Sero-prevalence of brucellosis in occupationally exposed people in Addis Ababa, Ethiopia. Ethiopian Medical Journal 44(3): 245-252.

8. Memish ZA, Almuneef M and Mah MW et al. (2002). Comparison of the Brucella Standard Agglutination Test with the ELISA IgG and IgM in patients with Brucella bacteremia. Diagnostic Microbiology and Infectious Disease 44: 129-132.

9. Mia AS and Islam H (1967). A preliminary study on incidence of bovine infertility and economic loss caused by it. Pakistan Veterinary Journal 12:12-15.

10. Mrunalini N, Reddy MS, Ramasastry P and Rao MR (2004). Seroepidemiology of human brucellosis in Andhra Pradesh. Indian Veterinary Journal 81(7): 744-747.

11. Mustafa AH and Nicoletti P (1995). FAO, WHO, OIE guidelines for a regional brucellosis control programme for the Middle East. FAO Workshop of Amman, Jordan; Ammended at The Round-Table of Maisons Alfort,France.http://www.fao.org/WAICENT/FAOINFO/Agricult/aga/agah/ID/ GUIDE-EN.htm.

12. OIE (2004). Chapter 2.3.1.Bovine Brucellosis. Manual of Diagnostic Tests and Vaccines for Terrestrial Animals. www.oie.int/esp/normes/mmanual/A_ooo52.htm. 


\section{A. Nahar and M. U. Ahmed}

13. Plommet (1971). Effect of brucellosis in bovine Reproductive Efficiency. In current Therapy in Theriogenology. $2^{\text {nd }}$ edn., (1986) by morrow, D. A., W. B. Saunders Co. Philadelphia. P.272.

14. Radostits OM, Gay CC, Blood DC and Hinchcliff KW (2000). Veterinary Medicin. $9^{\text {th }}$ edn., W. B. Saunders Company Ltd. 2000. PP.871, 882 .

15. Rahman MM, Chowdhury TIMF and Chowdhury MUA (1978). Investigation of brucellosis among cattle. Bangladesh Veterinary Journal 12(1-4):12-15.

16. Rahman MM, Chowdhury, TIMFR, Rahman A and Haque, F (1983). Seroprevalence of human and animal brucellosis in Bangladesh. Indian Veterinary Journal 60: 165.

17. Rahman MM, Haque M and Rahman MA (1988). Sero-prevalence of caprine and human brucellosis in some selected areas of Bangladesh. Bangladesh Veterinary Journal 22(1-2): 85-92.

18. Rahman MS, Han JC, Park J, Lee JH, Eo SK and Chae JS (2006). Prevalence of brucellosis and its association with reproductive problems in cows in Bangladesh. Veterinary Record 159:180-182.

19. Sarumathi C, Reddy TV and Sreedevi B (2003). Serological survey of bovine brucellosis in Andhra Pradesh.. Indian Journl of Dairy Science 56(6): 408-410.

20. Sharma K, Arun-Kumer, Thapliyal DC and Singh SP( 2003). Sero-epidemiology of brucellosis in bovines. Indian Journal of Animal Sceince 73(11):1235-1237.

21. Silva I, Dangolla A and Kulachelvy K (2000). Seroepidemiology of Brucella abortus infection in bovids in Sri Lanka. Preventive Veterinary Medicine 46: 51-59.

22. WHO (1971). Technical Report Series No. 464. Joint FAO/WHO Expert Committee on Brucellosis. $5^{\text {th }}$ Report. 